\title{
Science and Engineering Students' Difficulties With Fractions At Entry-Level To University
}

\author{
Johanna Coetzee ${ }^{a} \&$ Kuttickattu J. Mammen ${ }^{b}$ \\ aWalter Sisulu University, South Africa; bUniversity of Fort Hare, South Africa
}

ABSTRACT

This study was carried out at a South African university. The aim of the study was to test entrylevel students' fractions skills in order to facilitate teaching at appropriate levels. The sample consisted of 94 first-year entry level students ( 54 mainstream and 40 extended stream) who were enrolled for national diplomas in science and engineering, out of a population of 120 students. The instrument had 20 items, including three multiple choice questions (MCQs). The data were analyzed using Microsoft Excel 2013. The main finding was that entry-level students enrolled for engineering and science diplomas performed poorly in a test of numeracy skills. The average score $(47.8 \%)$ was regarded as a cause for concern, especially considering that the test was pitched at Grade 8 level. The study also found that students struggled to apply proportional reasoning when dealing with word problems. Mathematics teachers and lecturers need to be aware of students' difficulties and ought to attempt to assist them to overcome such challenges. It is hoped that this paper will be useful to mathematics curriculum implementers at school level, subject advisors at the district level, pre-service teacher educators at Teachers' colleges and universities, and university lecturers teaching mathematics at first year level.

KEYWORDS

mathematics education; numeracy; fractions; ratios;

proportions
ARTICLE HISTORY

Received 15 September 2016 Revised 10 November 2016 Accepted 22 February 2017

\section{Introduction}

A current theme in the mathematics literature revolves around the question whether students' difficulties with fractions have been resolved by the time they enrol at university (Booth et al., 2014; Duffin, 2003; Gabaldon, 2015;

\section{CORRESPONDENCE J Coetzee $\square$ hcoetzee@wsu.ac.za}

(C) 2017 Coetzee \& Mammen

Open Access terms of the Creative Commons Attribution 4.0 International License apply. The license permits unrestricted use, distribution, and reproduction in any medium, on the condition that users give exact credit to the original author(s) and the source, provide a link to the Creative Commons license, and indicate if they made any changes. (http://creativecommons.org/licenses/by/4.0/) 
Jukes \& Gilchrist, 2006; Livy \& Herbert, 2013; Schneider \& Siegler, 2010). Duffin (2003, p. 1) asserts that the terms "numeracy" and "higher education" seem anomalous. However, evidence points to the contrary (Schneider \& Siegler, 2010). Researchers have reported students to be underprepared for the numeracy demands in courses such as nursing and health sciences (Jukes \& Gilchrist, 2006), business (Boreland, 2016) and law (Gabaldon, 2015). Although research reports on numeracy demands on science and engineering students have been sparse, this research area has recently begun gaining momentum. The inadequacy might probably have been due to the assumption that competency in mathematics necessarily encompasses high levels of quantitative literacy. Interestingly, some people regard this as a reasonable assumption, especially for students who register for science and engineering courses. This is however not necessarily the case (Barwell, 2004; Houston et al., 2015; Wilson \& MacGillivray, 2007). While discussing challenges in teaching, the authors and their colleagues have on several occasions reflected on what they perceived as their science and engineering students' poor proficiency in fractions. According to Torbeyns et al. (2015), teachers should be informed of their students' difficulties with fractions in order to adjust their teaching to their students' current skills levels. The aim of the study was therefore to identify science and engineering students' prior knowledge in fractions at university entry level. The terms "numeracy" and "quantitative literacy" are considered as synonyms and used interchangeably in this paper.

Despite a strong association between numeracy and mathematics, these two are not equivalent. Roohr et al. (2014) assert that quantitative literacy is embedded in real-world contexts, and therefore lacks the more abstract and general nature of mathematics. Because of the context-based nature, quantitative literacy articulates the "power of practicality, whereas mathematics in turn articulates the "power of abstraction" (Bowie \& Frith, 2006, p. 29). Numeracy skills are however required by students enrolled for science and engineering diplomas. The United States National Mathematics Advisory Panel (NMAP) described fractions as "the most important foundational skill not presently developed" (NMAP, 2008, p. 18). Poor numeracy skills will detrimentally affect students' performance in mathematics, engineering, statistics and other related subjects (Cetin \& Ertekin, 2011; Torbeyns et al., 2015; Wilson \& MacGillivray, 2007).

The importance of mathematics cannot be overemphasised. Mathematics is a compulsory subject for further studies in science, technology and engineering (STEM). Furthermore, skills level in high school mathematics can be used to predict future qualifications and levels of job satisfaction and income (Rivera-Batiz, 1992). More specifically, research shows that there is a strong link between understanding of fractions and success in mathematics. Fractions play a central role in algebra (Booth et al., 2014; Siegler et al., 2012a; Siegler \& Lortie-Forgues, 2015) and influence performance in more advanced courses in mathematics (Booth \& Newton, 2012; Siegler et al., 2012b; Watts et al., 2014). "Fractions (along with the closely related concepts of ratios and proportion) are ubiquitous in algebra" (Bailey et al., 2015), in specific topics in mathematics such as geometry, probability and trigonometry (Pienaar, 2014, p. 2). Lesh et al. (1988, p. 93) argue that proportional reasoning is especially important, calling it the "capstone of elementary math" and the "cornerstone of high school 
math". Bone et al. (1984) assert that ratio and proportion are the two skills most frequently characterized by instructors of technical courses as essential. Knowledge of fractions indirectly determines career choices and eventual income levels (Titus, 1995). Quantitative literacy has been shown to influence the prospect of full-time employment (Naureen \& Vicki, 2012; Rivera-Batiz, 1992). Also, quantitative literacy has been found to influence the quality of judgement and decision making in consumerism and medical and financial contexts in people's personal lives, even amongst highly qualified communities (Reyna et al., 2009).

Difficulties with mathematics may commence early in the educational process (Bailey et al., 2015; Cai, 1995; Torbeyns et al., 2015). It is well-known that "mathematics is ruthlessly cumulative all the way back to counting to ten" (Pinker, 1998, p. 342), and even if lower level procedures are mastered, learning without understanding them will impair future performance and subsequent learning. Spaull and Kotze (2015, p. 14) describe this structure as "a hierarchy of knowledge and intellectual skill", and proceed to quote the description of the hierarchical nature of the subject given by Schollar (2008, p. 1):

Mathematics, however, is an hierarchical subject in which the development of increasingly complex cognitive abilities at each succeeding level is dependent on the progressive and cumulative mastery of its conceptual frameworks, starting with the absolutely fundamental basics of place value (the base-10 number system) and the four operations (calculation).

It therefore stands to reason that some of the problems with mathematics can be traced back to primary school mathematics, and more specifically, to the learning and teaching of fractions. The national report of the Department of Basic Education of South Africa pointed out in 2012 that the lack of understanding in basics of fraction was one of the factors that contributed to the low achievement in matriculation mathematics examinations in that year (DoBE, 2012). Problems with conceptual understanding of fractions are common amongst students and may last into adulthood (Siegler et al., 2012b; Siegler \& Thompson, 2014). In a survey conducted on adult skills, the Organization for Economic Co-operation and Development (OECD, 2013) found that only one in three adults was able to understand and interpret simple data and statistics in tables and graphs. Even in first world countries such as Italy and Spain, almost a third of the adults performed at or below the lowest level of proficiency in both literacy and numeracy (OECD, 2013). Proficiency in literacy and numeracy is closely related and also related to proficiency in problem solving in digital environments (OECD, 2013).

Torbeyns et al. (2015) found that difficulties with fractions are common, even amongst prospective teachers from various countries. It is therefore understandable that research on students' difficulties with fractions has been an ongoing activity. There is consensus amongst educational researchers that fractions are a complex and multifaceted construct (Brousseau et al., 2004; Lamon, 2001) Learners find fractions difficult to learn (Booth \& Newton, 2012; Lortie-Forgues et al., 2015) and teachers likewise find it a difficult topic to teach (Clarke, 2006; Ma, 1999). Ratio and proportion especially cause difficulties for students and teachers alike (Livy et al., 2013). In a study done in England on 
undergraduate nursing students' abilities to calculate drug dosages, only $7 \%$ correctly answered the questions on ratio and proportion, although the average score on the test was 55\% (Jukes \& Gilchrist, 2006).

\section{Research Method}

The present study involved entry-level Diploma students from a comprehensive university in the South Africa. In this university, the students are streamed as mainstream or extended stream, depending on their prior academic performance. If applicants do not qualify academically for the entrance requirements of their chosen diploma, they are placed in the extended stream, and allowed extra time to complete the qualification. Extended stream courses qualify for additional government subsidies. The sample consisted of university entry level students who were enrolled for mathematics, a service course for national diploma studies in engineering and science. Based on a request from the researchers, out of a population of 120 students in three cohorts (Electrical Engineering, Civil Engineering and Analytical Chemistry), 94 students (54 mainstream and 40 extended stream) voluntarily took part in the study.

Adopting a positivist paradigm and a quantitative research approach, the study applied a survey design. The instrument collected general data such as age, Grade 12 mathematics scores, gender, course and stream. The fractions part in the instrument consisted of 20 items, of which three were multiple choice questions (MCQs) and the rest open-ended calculations. The lead researcher compiled the instrument after a study of the pertinent literature, including various Trends in International Mathematics and Science studies (TIMSS). Questions were selected to cover the following topics: notation, magnitude and magnitude on a number line (B1); operations on fractions (B2); operations combined with SI unit conversions (B3); ratio and proportion (B4) and percentage and percentage increase and decrease (B5). The skills tested are required in all engineering and science courses. An attempt was made to cover four levels of skills in the test, namely knowing; performing routine procedures and/or measurements; using complex procedures and lastly, solving problems as envisaged by (DoBE, 2011a). The allocation of a question to one of the four categories mentioned above was not always made apparent. Long et al. (2014, p.8) assert that such allocation "depends on the level of knowledge acquired by the learner". The first category was 'knowing' and the allocation of questions to this category seemed simple, but in retrospect it was found to be more difficult than expected as Long et al. (2014) posited:

Even a seemingly simple category such as "knowing", can be problematic.... Whilst there is an element of memory involved, in that recalling facts, terms, basic concepts and answers forms part of this component, this component also embraces knowledge of specifics (terminology and specific facts), knowledge of ways and means of dealing with specifics and knowledge of the universal abstractions in a field (principles and generalisations, theories and structures) (Long et al., 2014, p. 4).

Hence, experienced mathematics lecturers from the same faculty were 
requested to analyse the test. They rated the degree of difficulty of each question in the questionnaire on a five point scale as either very easy, easy, moderate, difficult or very difficult. The vast majority of questions were rated as very easy, easy or moderate $(85.5 \%)$. Only $14.5 \%$ of the ratings indicated a difficult or very difficult option. The test was then piloted and slight modifications were made.

Data were collected during the third week of the semester. Data collection was managed by field workers, who emphasized that participation in the research project was voluntary and the upholding of the anonymity of respondents. Since data was required on every question, no time limit was set to complete the test. Furthermore, a decision was taken to allow calculators, since students were permitted to use calculators in all their assessments.

\section{Results and Discussion}

Microsoft Excel 2013 was used in the analysis of the data. The majority of the students participating in the study were in the mainstream (54 or 57\%) and the rest (40 or $43 \%)$ in the extended stream. The gender division of the sample was almost even at forty-eight (51\%) males and forty-six (49\%) females. The sample was composed of more engineering (47.9\%) than science (52.1\%) students. Majority (55 or 58.5\%) were in the 20-24 years age category. About a third (32 or $34.0 \%$ ) was considered to be "at risk" of failing mathematics based on Grade 12 mathematics scores below 50\% (Table 1). Another twenty-seven (28.7\%) students with Grade 12 mathematics scores of between 50-59\% were considered to be in need of support. Only $37.2 \%$ reported Grade 12 mathematics scores of above $59 \%$.

The Electrical engineering cohort's Grade 12 results were superior to those of the other two (Table 1). Also, seven students among the Electrical engineering cohort had Grade 12 Mathematics scores of $70 \%$ or above, whereas none in the science cohort had a similar score. Despite this, those in the Civil engineering cohort had a higher number of scores in the top category than the other two cohorts (Table 3).

Table 1. Contingency Table - Cohort and Self-Reported Mathematics Grade12 Score

\begin{tabular}{|l|c|c|c|c|c|c|c|c|}
\hline $\begin{array}{l}\text { Percentage } \\
\text { range }\end{array}$ & \multicolumn{7}{|c|}{ Cohort } & \multicolumn{2}{|}{} \\
\cline { 1 - 5 } $\begin{array}{c}\text { Mathematics } \\
\text { Grade } 12\end{array}$ & $\begin{array}{l}\text { Analytical } \\
\text { Chemistry }\end{array}$ & \multicolumn{2}{|c|}{$\begin{array}{c}\text { Civil } \\
\text { Engineering }\end{array}$} & \multicolumn{2}{|c|}{$\begin{array}{c}\text { Electrical } \\
\text { Engineering }\end{array}$} & \multirow{2}{*}{ Total } \\
\hline $0-29 \%$ & 0 & $0 \%$ & 0 & $0 \%$ & 0 & $0 \%$ & 0 & $0 \%$ \\
\hline $30-39 \%$ & 0 & $0 \%$ & 1 & $4 \%$ & 0 & $0 \%$ & 1 & $1 \%$ \\
\hline $40-49 \%$ & 31 & $63 \%$ & 0 & $0 \%$ & 1 & $5 \%$ & 32 & $34 \%$ \\
\hline $50-59 \%$ & 9 & $18 \%$ & 15 & $60 \%$ & 3 & $15 \%$ & 27 & $29 \%$ \\
\hline $60-69 \%$ & 9 & $18 \%$ & 6 & $24 \%$ & 9 & $45 \%$ & 24 & $26 \%$ \\
\hline $70-79 \%$ & 0 & $0 \%$ & 3 & $12 \%$ & 5 & $25 \%$ & 8 & $9 \%$ \\
\hline $80-100 \%$ & 0 & $0 \%$ & 0 & $0 \%$ & 2 & $10 \%$ & 2 & $2 \%$ \\
\hline Total & 49 & $100 \%$ & 25 & $100 \%$ & 20 & $100 \%$ & 94 & $100 \%$ \\
\hline
\end{tabular}

Not many students were confident when working with fractions. Only 40 $(42.6 \%)$ reported that they were confident, whilst $44(46.8 \%)$ were unsure. These 
figures show nexus to the test scores-the average test score was similar (47.8\%). Considering their choice of career, it stands to reason that most of the students from this sample ( 86 or $91.5 \%$ ) regarded mathematics as very important. This is significant, since Thomson and Hillman (2010) assert that students who value mathematics are more likely to be successful in their tertiary study endeavours.

The students' average scores per question have been summarised in Table 2, sorted in the descending order. B1-B5 in Table 2 refer to the topics covered, B1 for notation, magnitude and magnitude on a number line; B2 for operations on fractions; B3 for operations combined with SI unit conversions; B4 for ratio and proportion and B5 for percentage and percentage increase and decrease. The skills level in Table 2 refers to one of four levels of skills, namely knowing (K), performing routine procedures and/or measurements (R), using complex procedures $(\mathrm{C})$ and lastly solving problems $(\mathrm{S})$. There were five questions in each of these categories.

Table $2^{1}$. Frequency Distributions: Correct answers to Test Questions ( $\left.\mathrm{n}=94\right)$

\begin{tabular}{|c|c|c|c|c|c|c|c|c|c|c|}
\hline $\begin{array}{l}\text { Question } \\
\text { Number }\end{array}$ & $\begin{array}{l}\text { Skills } \\
\text { level }\end{array}$ & $\begin{array}{l}\text { Topic } \\
\text { s } \\
\text { cover }\end{array}$ & \multicolumn{2}{|c|}{$\begin{array}{l}\text { Analytical } \\
\text { Chemistry }\end{array}$} & \multicolumn{2}{|c|}{$\begin{array}{c}\text { Civil } \\
\text { Engineerin } \\
\mathrm{g}\end{array}$} & \multicolumn{2}{|c|}{$\begin{array}{c}\text { Electrical } \\
\text { Engineeri } \\
\text { ng }\end{array}$} & \multicolumn{2}{|c|}{ Total } \\
\hline $3 e$ & $\mathrm{~K}$ & B2 & 40 & $87 \%$ & 17 & $68 \%$ & 1 & $75 \%$ & 72 & $77 \%$ \\
\hline 5 & $\overline{\mathrm{R}}$ & $\overline{\text { B3 }}$ & 32 & $70 \%$ & 19 & $76 \%$ & 1 & $80 \%$ & 67 & $72 \%$ \\
\hline $3 b$ & $\mathrm{R}$ & B2 & 31 & $67 \%$ & 19 & $76 \%$ & 1 & $85 \%$ & 67 & $71 \%$ \\
\hline $3 d$ & $\mathrm{R}$ & B2 & 29 & $63 \%$ & 24 & $96 \%$ & 1 & $70 \%$ & 67 & $71 \%$ \\
\hline 1 & $\mathrm{~K}$ & B1 & 29 & $63 \%$ & 18 & $72 \%$ & 1 & $95 \%$ & 66 & $70 \%$ \\
\hline 7 & $\mathrm{C}$ & B4 & 28 & $61 \%$ & 17 & $68 \%$ & 8 & $40 \%$ & 53 & $60 \%$ \\
\hline 4 & $\mathrm{R}$ & B3 & 27 & $59 \%$ & 15 & $60 \%$ & 1 & $65 \%$ & 55 & $59 \%$ \\
\hline 11 & K & B5 & 27 & $59 \%$ & 15 & $60 \%$ & 1 & $55 \%$ & 53 & $58 \%$ \\
\hline 8 & $\mathrm{C}$ & B3 & 28 & $61 \%$ & 12 & $48 \%$ & 1 & $55 \%$ & 51 & $54 \%$ \\
\hline $2 \mathrm{a}$ & $\mathrm{C}$ & B1 & 22 & $48 \%$ & 15 & $60 \%$ & 1 & $65 \%$ & 50 & $54 \%$ \\
\hline $2 \mathrm{~b}$ & $\mathrm{C}$ & B1 & 23 & $50 \%$ & 14 & $56 \%$ & $\begin{array}{l}1 \\
2\end{array}$ & $65 \%$ & 50 & $54 \%$ \\
\hline 10 & C & B4 & 21 & $46 \%$ & 16 & $64 \%$ & 7 & $35 \%$ & 44 & $47 \%$ \\
\hline $3 a$ & $\mathrm{R}$ & B2 & 20 & $43 \%$ & 10 & $40 \%$ & 8 & $40 \%$ & 38 & $41 \%$ \\
\hline 13 & $\mathrm{~S}$ & B5 & 13 & $28 \%$ & 12 & $48 \%$ & 9 & $45 \%$ & 34 & $37 \%$ \\
\hline
\end{tabular}

${ }^{1}$ Percentages in this table were calculated as a proportion of the number of students who answered each question. In the rest of the paper, percentages were calculated as a fraction of 94, the sample size. It was assumed that students who did not offer an answer, 
did not know how to do the question, since they had almost unlimited time (Wilson \& MacGillivray 2007).

The average score (47.8\%) was disappointing indicating that most entrylevel engineering and science diploma students at this particular university in South Africa still struggle with fractions. The scores had a wide range (7\%-86\%). The standard deviation and the median were $19.6 \%$ and $50.5 \%$, respectively.

Table 3. Mainstream Averages compared to Extended Stream Averages

\begin{tabular}{|c|c|c|c|c|c|}
\hline $\begin{array}{c}\text { Descripti } \\
\text { on }\end{array}$ & \multicolumn{3}{|c|}{ Mainstream (54) } & \multicolumn{2}{c|}{ Extended Stream (40) } \\
\hline $\begin{array}{c}\text { average } \\
\text { overall } \\
\text { scores }\end{array}$ & $\begin{array}{c}\text { Electrical } \\
\text { Engineering } \\
(20)\end{array}$ & $\begin{array}{c}\text { Civil } \\
\text { Engineeri } \\
\text { ng (17) }\end{array}$ & $\begin{array}{c}\text { Analytical } \\
\text { Chemistry } \\
(17)\end{array}$ & $\begin{array}{c}\text { Civil } \\
\text { Enginee } \\
\text { ring (8) }\end{array}$ & $\begin{array}{c}\text { Analytical } \\
\text { Chemistry } \\
(32)\end{array}$ \\
\hline $\begin{array}{c}\text { average } \\
\text { percentag } \\
\text { e }\end{array}$ & $50.8 \%$ & $57 \%$ & $51 \%$ & $44 \%$ & $39 \%$ \\
\hline $\begin{array}{c}\text { standard } \\
\text { deviation }\end{array}$ & $15.9 \%$ & $17 \%$ & $15 \%$ & $20 \%$ & $19 \%$ \\
\hline $\begin{array}{c}\text { per } \\
\text { stream }\end{array}$ & \multicolumn{2}{|c|}{$53.5 \%$ (S.D. $=16.6 \%)$} & $40.1 \%$ (S.D. $=20.9 \%)$ \\
\hline sample & \multicolumn{4}{|c|}{$47.8 \%$} \\
\hline
\end{tabular}

The spread of the B scores (the average test scores) is tabulated (Table 4). Only 30 out of the $94(31.9 \%)$ students scored above $60 \%$ for the test.

Table 4. Contingency Table-Cohort and B Score

\begin{tabular}{|c|c|c|c|c|c|c|c|c|}
\hline \multirow{3}{*}{$\begin{array}{l}\text { B Score } \\
0 \text { to } 39 \\
\end{array}$} & \multicolumn{6}{|c|}{ Cohort } & \multirow{2}{*}{\multicolumn{2}{|c|}{ Total }} \\
\hline & \multicolumn{2}{|c|}{$\begin{array}{l}\text { Analytical } \\
\text { Chemistry }\end{array}$} & \multicolumn{2}{|c|}{$\begin{array}{c}\text { Civil } \\
\text { Engineering }\end{array}$} & \multicolumn{2}{|c|}{$\begin{array}{c}\text { Electrical } \\
\text { Engineering }\end{array}$} & & \\
\hline & 24 & $49.0 \%$ & 6 & $24.0 \%$ & 4 & $\begin{array}{l}20.0 \\
\%\end{array}$ & 34 & $36.2 \%$ \\
\hline 40 to 60 & 12 & $24.5 \%$ & 8 & $32.0 \%$ & 10 & $\begin{array}{l}50.0 \\
\%\end{array}$ & 30 & $31.9 \%$ \\
\hline 61 to 100 & 13 & $26.5 \%$ & 11 & $44.0 \%$ & 6 & $\begin{array}{l}30.0 \\
\%\end{array}$ & 30 & $31.9 \%$ \\
\hline Total & 49 & $100 \%$ & 25 & $100 \%$ & 20 & $\begin{array}{l}100 \\
\%\end{array}$ & 94 & $100 \%$ \\
\hline
\end{tabular}

Of the five sections in the test, namely notation, magnitude and magnitude on a number line (B1), operations on fractions (B2), operations combined with SI unit conversions (B3), ratio and proportion (B4) and percentage and percentage increase and decrease (B5), students performed best in operations combined with SI unit conversions (B3) and worst in the section on percentages (B5). The average score for only two of the sections, namely B1 and B3, were higher than 50\%, while the mean scores for B4 and B5 were below 40\% (Table 5). 
Table 5. Central tendency \& dispersion: test scores in percentages $(n=94)$

\begin{tabular}{|c|c|c|c|c|c|c|c|}
\hline Scores & Mean & S.D. & Min & Quartile 1 & Median & Quartile 3 & Max \\
\hline B1 & 58.8 & 38.2 & 0.0 & 33.0 & 67.0 & 100.0 & 100.0 \\
\hline B2 & 46.9 & 20.2 & 0.0 & 29.0 & 43.0 & 57.0 & 86.0 \\
\hline B3 & 61.4 & 33.4 & 0.0 & 33.0 & 67.0 & 100.0 & 100.0 \\
\hline B4 & 39.6 & 29.4 & 0.0 & 25.0 & 50.0 & 50.0 & 100.0 \\
\hline B5 & 32.2 & 24.7 & 0.0 & 0.0 & 33.0 & 33.0 & 100.0 \\
\hline B & 47.8 & 19.6 & 7.0 & 31.0 & 50.5 & 63.0 & 86.0 \\
\hline
\end{tabular}

The data revealed a significant relationship between the self-reported Grade 12 Mathematics score and the B1 Score and a statistically significant relationship between the self-reported Grade 12 Mathematics score and both the B3 Score and the average score for the test (the B score) (Figure 1 and Tables 6 and 7). According to Gravetter and Wallnau (2009), correlations are statistically significant at the 0.05 level for $n=94$ if $|r| \geq 0.203$ and practically significant if $|r| \geq 0.300$.

Table 6. Pearson Product Moment Correlations-B1 (Notation, magnitude and magnitude on a number line) score to B score and Mathematics Grade 12 ( $\mathrm{n}=$ 94) score

\begin{tabular}{|l|c|}
\hline & Mathematics Grade 12 \\
\hline B1 score & 0.347 \\
\hline B2 score & 0.110 \\
\hline B3 score & 0.228 \\
\hline B4 score & 0.169 \\
\hline B5 score & 0.030 \\
\hline B score & 0.291 \\
\hline
\end{tabular}

Table 7. Contingency Table - Mathematics Grade 12 and B Scores

\begin{tabular}{|c|c|c|c|c|c|c|c|c|}
\hline \multirow{3}{*}{$\begin{array}{l}\text { B } \\
\text { Score } \\
0- \\
39\end{array}$} & \multicolumn{8}{|c|}{ Mathematics Grade 12} \\
\hline & \multicolumn{2}{|c|}{$30-49 \%$} & \multicolumn{2}{|c|}{$50-59 \%$} & \multicolumn{2}{|c|}{$60-100 \%$} & \multicolumn{2}{|c|}{ Total } \\
\hline & 19 & $58 \%$ & 9 & $33 \%$ & 6 & $18 \%$ & 34 & $36 \%$ \\
\hline $\begin{array}{l}40- \\
100\end{array}$ & 14 & $42 \%$ & 18 & $67 \%$ & 28 & $82 \%$ & 60 & $64 \%$ \\
\hline Total & 33 & $100 \%$ & 27 & $100 \%$ & 34 & $100 \%$ & 94 & $100 \%$ \\
\hline
\end{tabular}




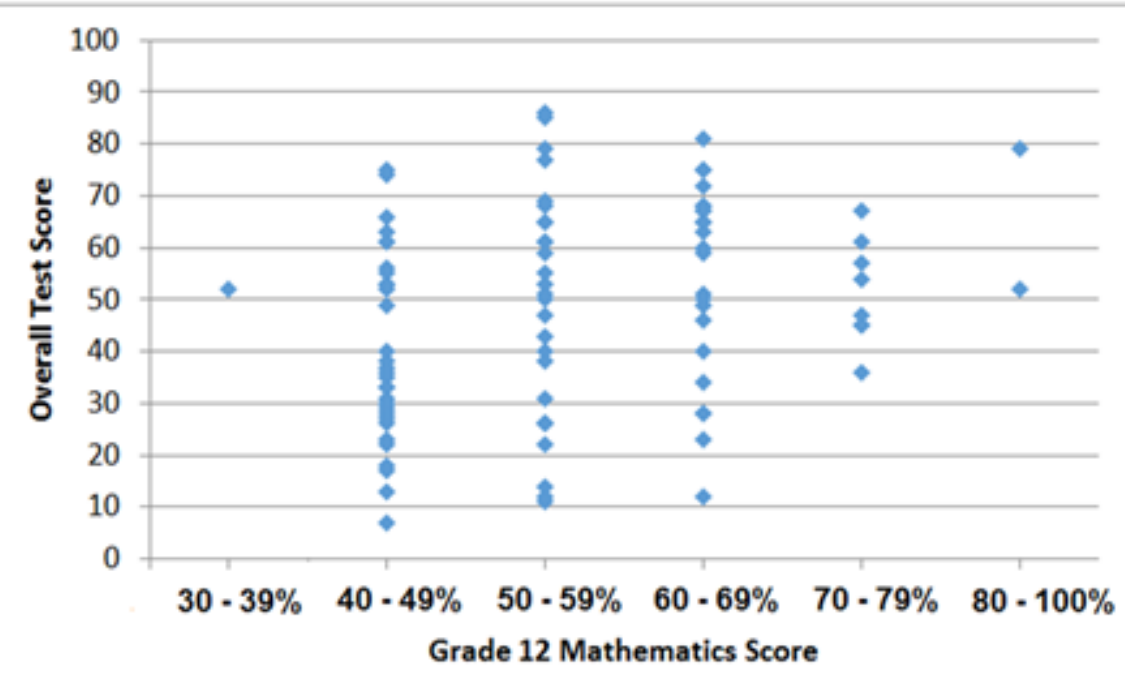

Figure 1. Relationship between Grade12 Mathematics Score and Overall Test Score

A medium size difference (Cohen's $d=0.73$ ) was detected between the average test scores (B score) of the mainstream and the extended stream (Table 8). Medium size differences were also indicated (Cohen's $d=0.66$; Cohen's $d=$ 0.67 respectively) between the B1 and B3 scores of the two cohorts.

Table 8. t-Tests: B1 to B Score by Mainstream $(n=54)$ and Extended Stream (n $=40)$

\begin{tabular}{|c|c|c|c|c|c|c|c|c|}
\hline Variable & Stream & Mean & S.D & $\begin{array}{l}\text { Diffe- } \\
\text { rence }\end{array}$ & $\mathrm{t}$ & d.f. & $\begin{array}{c}p \\
\text { (d.f.=92) }\end{array}$ & $\begin{array}{c}\text { Cohen's } \\
\mathrm{d}\end{array}$ \\
\hline \multirow[t]{2}{*}{$\begin{array}{l}\text { B1 } \\
\text { Score }\end{array}$} & Main & 69.07 & 35.48 & \multirow[t]{2}{*}{24.07} & \multirow[t]{2}{*}{3.18} & \multirow[t]{2}{*}{92} & \multirow[t]{2}{*}{0.002} & \\
\hline & Extended & 45.00 & 37.48 & & & & & Medium \\
\hline \multirow[t]{2}{*}{$\begin{array}{l}\text { B2 } \\
\text { Score }\end{array}$} & Main & 48.76 & 19.28 & \multirow{2}{*}{4.46} & \multirow[t]{2}{*}{1.06} & \multirow[t]{2}{*}{92} & \multirow[t]{2}{*}{0.292} & \multirow[t]{2}{*}{$\mathrm{n} / \mathrm{a}$} \\
\hline & Extended & 44.30 & 21.32 & & & & & \\
\hline \multirow[t]{2}{*}{$\begin{array}{l}\text { B3 } \\
\text { Score }\end{array}$} & Main & 70.46 & 27.27 & \multirow[t]{2}{*}{21.34} & \multirow[t]{2}{*}{3.22} & \multirow[t]{2}{*}{92} & \multirow[t]{2}{*}{0.002} & 0.67 \\
\hline & Extended & 49.13 & 37.05 & & & & & Medium \\
\hline \multirow[t]{2}{*}{$\begin{array}{l}\text { B4 } \\
\text { Score }\end{array}$} & Main & 43.52 & 29.61 & \multirow{2}{*}{9.14} & \multirow[t]{2}{*}{1.50} & \multirow[t]{2}{*}{92} & \multirow[t]{2}{*}{0.137} & \multirow[t]{2}{*}{$\mathrm{n} / \mathrm{a}$} \\
\hline & Extended & 34.38 & 28.69 & & & & & \\
\hline \multirow[t]{2}{*}{$\begin{array}{l}\text { B5 } \\
\text { Score }\end{array}$} & Main & 35.69 & 25.06 & \multirow[t]{2}{*}{8.29} & \multirow[t]{2}{*}{1.62} & \multirow[t]{2}{*}{92} & \multirow[t]{2}{*}{0.109} & \multirow[t]{2}{*}{$\mathrm{n} / \mathrm{a}$} \\
\hline & Extended & 27.40 & 23.80 & & & & & \\
\hline \multirow[t]{2}{*}{ B Score } & Main & 53.52 & 16.62 & \multirow[t]{2}{*}{13.47} & \multirow[t]{2}{*}{3.48} & \multirow[t]{2}{*}{92} & \multirow[t]{2}{*}{.001} & \multirow{2}{*}{$\begin{array}{c}0.73 \\
\text { Medium } \\
\end{array}$} \\
\hline & Extended & 40.05 & 20.91 & & & & & \\
\hline
\end{tabular}


The meta-cognition of the students was probed in the last question (Q15) by asking them to rate their scores in the test:

Please indicate what, in your opinion, you most likely scored on this test by writing down the letter of the score category:

\begin{tabular}{|l|l|l|l|l|}
\hline$A: 0-19 \%$ & $B: 20-39 \%$ & $C: 40-59 \%$ & $D: 60-79 \%$ & $E: 80-100 \%$ \\
\hline
\end{tabular}

A statistically significant correlation was measured between the answers (B15 scores, Figure 2) and the B4 and B scores (Table 9).

Table 9. Contingency Table - Cohort and B15

\begin{tabular}{|c|c|c|c|c|c|c|c|c|}
\hline \multirow{2}{*}{ B15 } & \multicolumn{7}{|c|}{ Cohort } & \multirow{2}{*}{} \\
\cline { 2 - 8 } & $\begin{array}{c}\text { Analytical } \\
\text { Chemistry }\end{array}$ & \multicolumn{2}{|c|}{$\begin{array}{c}\text { Civil } \\
\text { Engineering }\end{array}$} & \multicolumn{2}{c|}{$\begin{array}{c}\text { Electrical } \\
\text { Engineering. }\end{array}$} & \multicolumn{2}{|c}{ Total } \\
\hline $0-19 \%$ & 1 & $2.1 \%$ & 2 & $8.0 \%$ & 0 & $0.0 \%$ & 3 & $3.2 \%$ \\
\hline $\begin{array}{c}20- \\
39 \%\end{array}$ & 9 & $18.8 \%$ & 2 & $8.0 \%$ & 1 & $5.0 \%$ & 12 & $12.9 \%$ \\
\hline $\begin{array}{c}40- \\
59 \%\end{array}$ & 18 & $37.5 \%$ & 10 & $40.0 \%$ & 6 & $30.0 \%$ & 34 & $36.6 \%$ \\
\hline $\begin{array}{c}60- \\
79 \%\end{array}$ & 11 & $22.9 \%$ & 7 & $28.0 \%$ & 7 & $35.0 \%$ & 25 & $26.9 \%$ \\
\hline $\begin{array}{c}80- \\
100 \%\end{array}$ & 9 & $18.8 \%$ & 4 & $16.0 \%$ & 6 & $30.0 \%$ & 19 & $20.4 \%$ \\
\hline Total & 48 & $100 \%$ & 25 & $100 \%$ & 20 & $100 \%$ & 93 & $100 \%$ \\
\hline
\end{tabular}

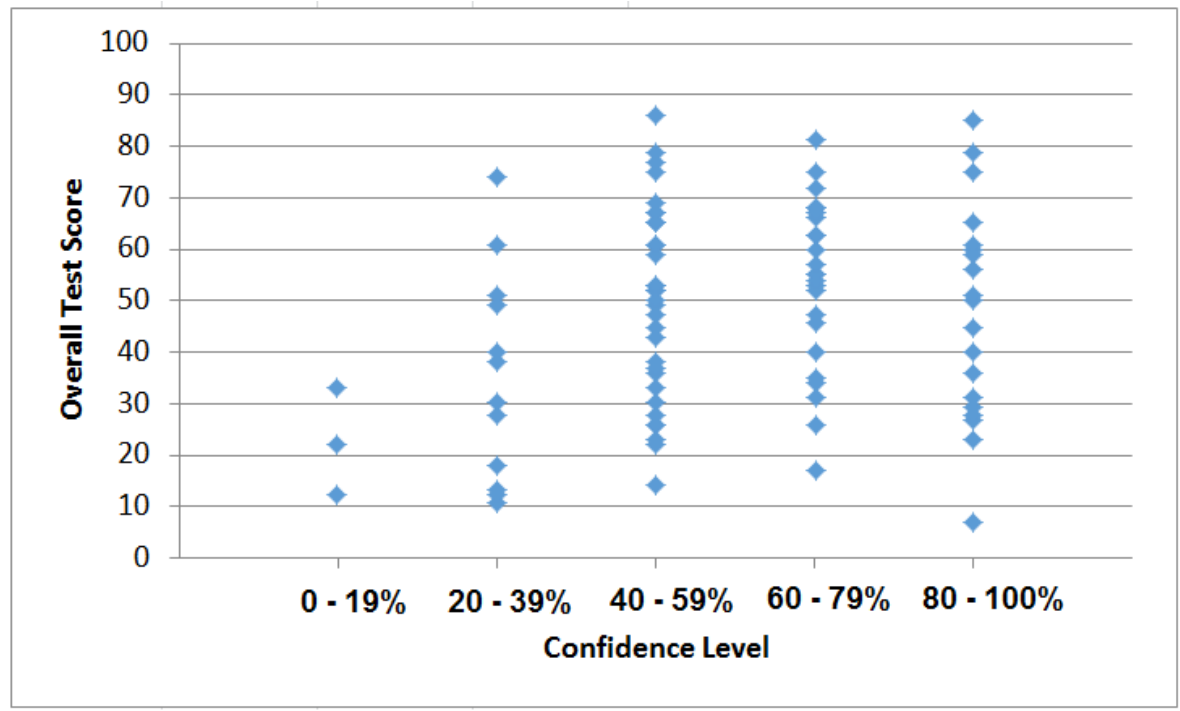

Figure 2. Relationship between Meta-cognition or Confidence level (B15) and Overall Test Score (B Score)

NOTATION, MAGNITUDE \& MAGNITUDE ON A NUMBER LINE (B1, $58.8 \%$ AVERAGE) (Q1 \& 2A, 2B) 
The first question, along with four others, namely Questions 3a ,3e and Questions 3c and 3d, were discussed in another article (Coetzee \& Mammen, 2016), since the data gathered from these questions pointed to language challenges with fractions terminology.

The second question tested knowledge of decimal fraction magnitude on a number line. This section is mentioned in the Grade 6 National Curriculum and Assessment Policy Statement (CAPS) document under "Recognizing, ordering and place value of decimal fractions" (DoBE, 2011c, p. 17). A portion of the number line was provided, with the endpoints indicated as zero and 0.4 (Figure 3 ). The line segment was subdivided into 10 equal parts. Two values, $x$ and $y$, had to be read from the line segment.

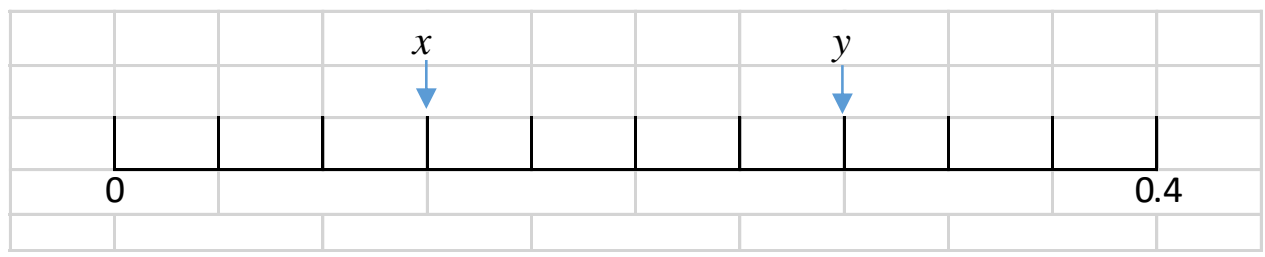

Figure 3. Line segment for answering Question 2

Only $50 \%$ of the students in the sample reported the value of $x$ correctly (Table 10). Although the Civil engineering mainstream scored higher than the other cohorts $(64.7 \%)$, it remains disconcerting that $34.5 \%$ of the mainstream Civil engineering students did not manage to answer this question correctly, since these students are expected to be able to work with scale measures in subjects such as Drawing and Survey. The correct answers for the first number read from the line segment correlated almost perfectly with the correct answers given for the second number. The errors committed are thus interpreted as different versions of incorrect subdivisions of the given interval. In such a case, it stands to reason that a mistake in reading the value of $x$, will necessarily lead to a mistake in reading the value of $y$. Despite an odd number of subdivisions (5) between zero and 0.2 , which meant that the midpoint between zero and $0.2 \mathrm{did}$ not coincide with a subdivision, some students indicated it as such and hence concluded that this point was 0.1. A number of students indicated the first of the subdivisions following zero as 0.22 and the subsequent ones as $0.24 ; 0.26 ; 0.28$; and so forth, up to 0.38 followed by 0.4 (Figure 4).

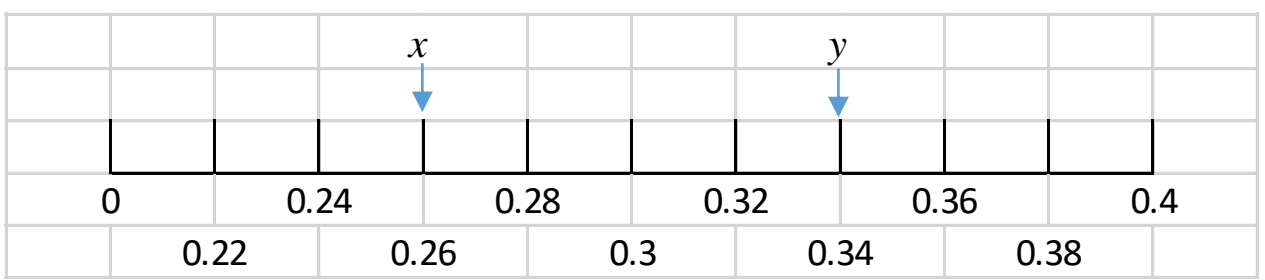

Figure 4. Incorrect subdivision for Question 2 
This division seemed to work out perfectly, but for the fact that the distance between zero and the first subdivision was $\frac{22}{100}$ units and the distance between each successive subdivision, was substantially smaller at $\frac{2}{100}$ units.

Table 10. Scores for Question 2

\begin{tabular}{|c|c|c|c|c|c|}
\hline \multirow[t]{2}{*}{ Question 2} & & \multicolumn{2}{|l|}{ Mainstream } & \multicolumn{2}{|c|}{ Extended Stream } \\
\hline & $\begin{array}{l}\text { Electrical } \\
\text { Engineerin } \\
\mathrm{g}(20)\end{array}$ & $\begin{array}{c}\text { Civil } \\
\text { Engineering } \\
(17)\end{array}$ & $\begin{array}{l}\text { Analytical } \\
\text { Chemistry } \\
\text { (17) }\end{array}$ & $\begin{array}{l}\text { Civil } \\
\text { Enginee } \\
\text { ring } \\
(8)\end{array}$ & $\begin{array}{c}\text { Analytical } \\
\text { Chemistry } \\
\text { (32) }\end{array}$ \\
\hline $\begin{array}{l}\text { correct } \\
\text { answers for } \\
\text { Q2a }\end{array}$ & $13(65.0 \%)$ & $11(64.7 \%)$ & $10(58.8 \%)$ & $4(50 \%)$ & $12(37.5 \%)$ \\
\hline $\begin{array}{l}\text { correct } \\
\text { answers per } \\
\text { stream }\end{array}$ & \multicolumn{3}{|c|}{$34(63 \%)$} & \multicolumn{2}{|c|}{$16(40 \%)$} \\
\hline sample Q2a & \multicolumn{5}{|c|}{$50(53.2 \%)$} \\
\hline $\begin{array}{l}\text { correct } \\
\text { answers for } \\
\text { Q2b }\end{array}$ & $13(65 \%)$ & $9(52.9 \%)$ & $10(58.8 \%)$ & $\begin{array}{c}5 \\
(62.5 \%)\end{array}$ & $13(40.6 \%)$ \\
\hline $\begin{array}{l}\text { correct } \\
\text { answers per } \\
\text { stream }\end{array}$ & \multicolumn{3}{|c|}{$32(59.3 \%)$} & \multicolumn{2}{|c|}{$18(45 \%)$} \\
\hline sample Q2b & & & $0(53.2 \%)$ & & \\
\hline
\end{tabular}

The summary of the scores for Cohort for B1 (Notation, magnitude and magnitude on a number line) is given in Table 11.

Table 11. Contingency Table - Cohort and B1 score

\begin{tabular}{|c|c|c|c|c|c|c|c|c|}
\hline \multirow{3}{*}{\begin{tabular}{l}
\multicolumn{1}{c}{$\begin{array}{l}\text { B1 } \\
\text { Score }\end{array}$} \\
0 to \\
39
\end{tabular}} & \multicolumn{6}{|c|}{ Cohort } & \multirow{2}{*}{\multicolumn{2}{|c|}{ Total }} \\
\hline & \multicolumn{2}{|c|}{$\begin{array}{l}\text { Analytical } \\
\text { Chemistry } \\
\text { (49) }\end{array}$} & \multicolumn{2}{|c|}{$\begin{array}{c}\text { Civil } \\
\text { Engineering } \\
(25)\end{array}$} & \multicolumn{2}{|c|}{$\begin{array}{c}\text { Electrical Engineering } \\
(20)\end{array}$} & & \\
\hline & 26 & $53 \%$ & 9 & $36 \%$ & 7 & $35 \%$ & 42 & $45 \%$ \\
\hline $\begin{array}{l}40 \text { to } \\
100\end{array}$ & 23 & $47 \%$ & 16 & $64 \%$ & 13 & $65 \%$ & 52 & $55 \%$ \\
\hline \multirow[t]{2}{*}{ Total } & 49 & $100 \%$ & 25 & $100 \%$ & 20 & $100 \%$ & 94 & $100 \%$ \\
\hline & \multicolumn{8}{|c|}{$\mathrm{Chi}^{2}($ d.f. $=2, \mathrm{n}=94)=2.91 ; \mathrm{p}=.233$} \\
\hline
\end{tabular}

OPERATIONS ON FRACTIONS (B2, 46.8\% AVERAGE) (Q 3A-F \& Q9)

In Question 3b, students had to calculate $\frac{1}{5}$ of a decimal fraction - a Grade 6 skill, which is also revised in Grades 7 and 8 (DoBE, 2011c, p. 17). 
Only $71 \%$ of the students were able to calculate the answer correctly, which is disconcertingly low for such a basic skill, especially considering that all the students had access to calculators.

In the last question of this section (Q9), students had to calculate how much sugar remained in a dish if a fraction $\left(\frac{1}{4}\right)$ of the sugar was spilt. This skill is prescribed in the Grade 6 syllabus (DoBE, 2011c, p. 15), yet only $24.5 \%$ of the students in the sample managed to answer correctly (Table 12). Students who gave the incorrect answer, mostly failed to calculate the amount of sugar spilt as a ratio of the original amount before subtracting from the original amount, i.e. they calculated $0.7 \mathrm{~kg}-\frac{1}{4}$, instead of calculating $0.7 \mathrm{~kg}-\left(\frac{1}{4}\right.$ of $\left.0.7 \mathrm{~kg}\right)$. They therefore also committed the error of subtracting a unit-less amount $\left(\frac{1}{4}\right)$ from an amount representing units $(0.7 \mathrm{~kg})$. The scores for these questions are similar to those achieved by university calculus students in a study involving units conducted in the United States. Of the 169 students tested in the former study, only forty five $(26,6 \%)$ gave correct units for all of the tasks (Dorko \& Speer, 2014).

Table 12. Scores for Question 9

\begin{tabular}{|c|c|c|c|c|c|}
\hline Question & \multicolumn{3}{|c|}{ Mainstream } & \multicolumn{2}{c|}{ Extended Stream } \\
\hline & $\begin{array}{c}\text { Electrical } \\
\text { Engineering } \\
(20)\end{array}$ & $\begin{array}{c}\text { Civil } \\
\text { Engineering } \\
(17)\end{array}$ & $\begin{array}{c}\text { Analytical } \\
\text { Chemistry } \\
(17)\end{array}$ & $\begin{array}{c}\text { Civil } \\
\text { Engineering } \\
(8)\end{array}$ & $\begin{array}{c}\text { Analytical } \\
\text { Chemistry } \\
(32)\end{array}$ \\
\hline $\begin{array}{c}\text { correct } \\
\text { answers }\end{array}$ & $7(35 \%)$ & $5(29.4 \%)$ & $4(23.5 \%)$ & $2(25 \%)$ & $5(15.6 \%)$ \\
\hline $\begin{array}{c}\text { correct } \\
\text { answers } \\
\text { per } \\
\text { stream }\end{array}$ & \multicolumn{3}{|c|}{$16(29.6 \%)$} & $7(17.5 \%)$ \\
\hline sample & \multicolumn{5}{|c}{$23(24.5 \%)$} \\
\hline
\end{tabular}

In Question 3f, students' conceptual understanding of $3 \div \frac{1}{2}$ was tested by providing a picture of three apples. Appropriate drawings were made by $36 \%$ of the students, depicting the correct answer to the question (Table 13). Students were required to draw 6 half apples, as depicted by Vuyo's suitable drawing in Figure 5. 


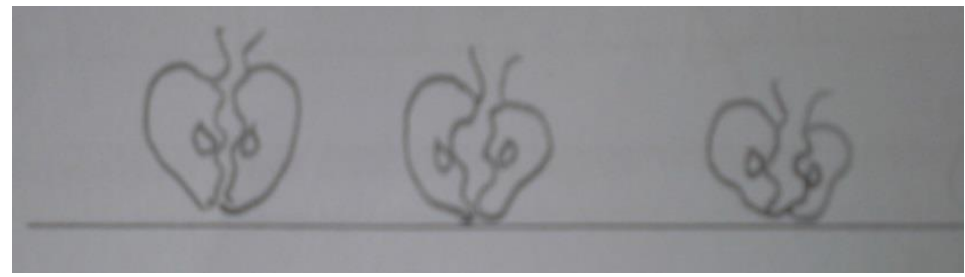

Figure 5. Vuyo's drawing made in response to Question $3 \mathrm{f}$

Although many students realised that the answer was supposed to be six, they did not necessarily relate the six to halves. Numerous answers depicted one apple divided into six portions, which apparently satisfied the need to have six elements in the answer.

Peter realised that an answer consisting of 6 whole units was incorrect, and that fractional portions were called for, and thus changed his answer to reflect these (Figure 6).

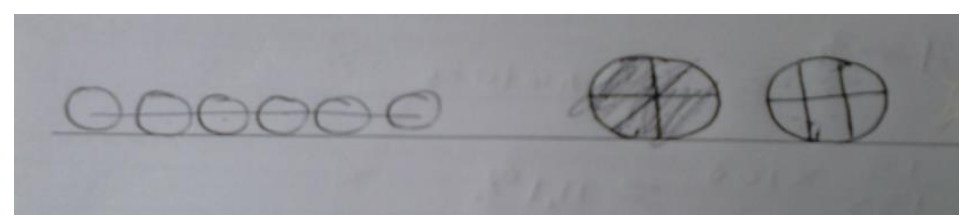

Figure 6. Peter's drawing in response to Question $3 \mathrm{f}$

Peter hence realised that the fractions in his first circular drawing were unequal, and attempted to correct it. He however ended up with four parts equal in size, but unequal in size to the other two parts.

Sam in turn reported the answer as six halves, but Sam's drawing (Figure 7) did not correspond to his written answer, and contained six parts, but not six halves. The drawing he made was similar to Peter's.

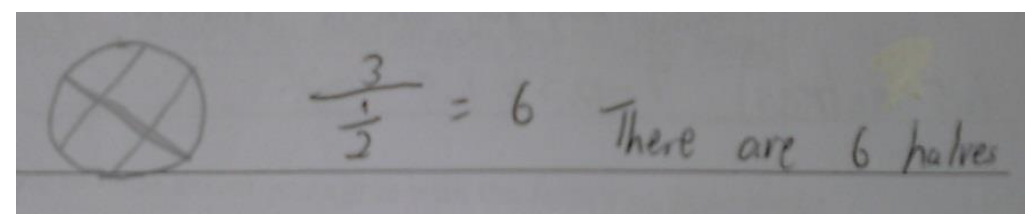

Figure 7. Sam's drawing in response to Question $3 \mathrm{f}$

Sam was able to find the correct answer, but did not display accurate conceptual understanding of the answer.

Table 13. Scores for Question 3f

\begin{tabular}{|c|c|c|c|c|c|}
\hline Description & & \multicolumn{2}{|c|}{ Mainstream } & \multicolumn{2}{|c|}{ Extended Stream } \\
\hline $\begin{array}{l}\text { Scores for } \\
\text { Question 3f }\end{array}$ & $\begin{array}{c}\text { Electrical } \\
\text { Engineering } \\
(20)\end{array}$ & $\begin{array}{c}\text { Civil } \\
\text { Enginee } \\
\text { ring } \\
(17)\end{array}$ & $\begin{array}{c}\text { Analytical } \\
\text { Chemistry } \\
\text { (17) }\end{array}$ & $\begin{array}{c}\text { Civil } \\
\text { Engineering } \\
\text { (8) }\end{array}$ & $\begin{array}{c}\text { Analytical } \\
\text { Chemistry } \\
\text { (32) }\end{array}$ \\
\hline
\end{tabular}




\begin{tabular}{|l|c|c|c|c|c|}
\hline $\begin{array}{l}\text { correct } \\
\text { answers }\end{array}$ & $1(5 \%)$ & $6(35 \%)$ & $5(29.4 \%)$ & $1(13 \%)$ & $14(35 \%)$ \\
\hline $\begin{array}{l}\text { correct } \\
\text { answers } \\
\text { per stream }\end{array}$ & \multicolumn{5}{|c|}{$12(22.2 \%)$} \\
\hline Sample & \multicolumn{5}{|c|}{$27(28.7 \%)$} \\
\hline
\end{tabular}

The summary of the scores for cohort for B2 (Operations on fractions) is given in Table 14.

Table 14. Contingency Table - Cohort and B2 Score

\begin{tabular}{|c|c|c|c|c|c|c|c|c|}
\hline \multirow{3}{*}{$\begin{array}{l}\text { B2 Score } \\
0 \text { to } 39\end{array}$} & \multicolumn{6}{|c|}{ Cohort } & \multirow{2}{*}{\multicolumn{2}{|c|}{ Total }} \\
\hline & \multicolumn{2}{|c|}{$\begin{array}{c}\text { Analytical } \\
\text { Chemistry } \\
(49)\end{array}$} & \multicolumn{2}{|c|}{$\begin{array}{c}\text { Civil } \\
\text { Engineering } \\
(25) \\
\end{array}$} & \multicolumn{2}{|c|}{$\begin{array}{c}\text { Electrical } \\
\text { Engineering } \\
(20) \\
\end{array}$} & & \\
\hline & 17 & $(35 \%)$ & 6 & $(24 \%)$ & 6 & $(30 \%)$ & 29 & $(31 \%)$ \\
\hline 40 to 100 & 32 & $65 \%$ & 19 & $76 \%$ & 14 & $70 \%$ & 65 & $69 \%$ \\
\hline Total & 49 & $100 \%$ & 25 & $100 \%$ & 20 & $100 \%$ & 94 & $100 \%$ \\
\hline \multicolumn{9}{|c|}{$\mathrm{Chi}^{2}($ d.f. $=2, \mathrm{n}=94)=0.90 ; \mathrm{p}=.639$} \\
\hline
\end{tabular}

\section{OPERATIONS COMBINED WITH SI UNIT CONVERSIONS (B3, 61.4\% AVERAGE) (Q 4, 5 \& 8)}

Both Questions four and five involved SI unit conversions, combined with an operation on a decimal fraction; division for Question four and addition for Question five (DoBE 2011c, p. 26). In Question four, students had to add two measurements of which one was an integer and the other a fraction. One measurement was however given in grams whereas the other was given in kilograms. In Question five, students had to calculate how many smaller containers of oil were required to fill one bigger container. The smaller container's volume was given in millilitres, whereas the bigger one's was given in litres. In both questions students needed to do unit conversions, but students clearly found the addition in Question five easier than the division in Question four. The proportion of correct answers for these two questions differed substantially at $57 \%$ and $72 \%$, respectively.

In Question eight two prices were provided for sugar - one for a $500 \mathrm{~g}$ pack of sugar and another for a $2.5 \mathrm{~kg}$ pack of sugar. Students had to calculate which option was cheaper, and were required to convert to a common unit. One method was to convert $2.5 \mathrm{~kg}$ to $2500 \mathrm{~g}$ and hence multiply the first price by 5 , since $\frac{2500}{500}=5$. Just over $50 \%$ of the students managed to do this correctly (Table 15). A common mistake was to divide by 1,000 , instead of multiplying by 1,000 , when converting from $\mathrm{kg}$ to $\mathrm{g}$. This mistake points to rote manipulation that lacks conceptual understanding. Another incorrect procedure was to multiply the mass $(500 \mathrm{~g})$ by the price ( $\mathrm{R}$ 5.27) to arrive at $\mathrm{R} \mathrm{2,635.} \mathrm{Students} \mathrm{following}$ this incorrect procedure hence understood the given price to be per one gram of sugar, instead of per packet of sugar. The correct answer involved multiple steps. Some students executed the first step correctly, but did not carry through, 
and therefore could not make the correct decision. An example of such a method is to first convert the price for the $2.5 \mathrm{~kg}$ pack of sugar to price per $\mathrm{kg}$, and then to stop. The second step, which was missing, would have been to also convert the price for the $500 \mathrm{~g}$ pack to a price per $\mathrm{kg}$, and then to compare the prices.

A study conducted in Italy on consumer choice (Graffeo et al., 2015) used a field experiment that showed marked similarities to Question eight in this study. During the experiment a product was made available, with different initial prices and discounts, at two shops. One of the deals was better than the other, and consumers had to pick the better one and describe the arithmetic operations used in their decision. The researchers classified the approaches used by the consumers as either "complete" or "partial". "Complete" refers to decisions taken after all the arithmetic operations required to solve the problem were calculated. "Partial" referred to decisions taken after only some of the operations were calculated. The researchers came to the conclusion that higher levels of numeracy were associated with the "complete" decision approach, which enabled the consumers to make a better quality purchase decision. The students involved in the current study, who had incomplete answers to Question eight, therefore used the "partial" decision approach, possibly demonstrating lower levels of numeracy. Wilson and MacGillivray (2007) assert that success rates fall rapidly when answers require multiple steps to be performed.

Table 15. Scores for Question 8

\begin{tabular}{|l|c|c|c|c|c|}
\hline Question 8 & \multicolumn{2}{|c|}{ Mainstream } & \multicolumn{2}{c|}{ Extended Stream } \\
\hline $\begin{array}{l}\text { Scores for } \\
\text { Question 8 }\end{array}$ & $\begin{array}{c}\text { Electrical } \\
\text { Engineeri } \\
\text { ng (20) }\end{array}$ & $\begin{array}{c}\text { Civil } \\
\text { Engineering } \\
(17)\end{array}$ & $\begin{array}{c}\text { Analytical } \\
\text { Chemistry } \\
(17)\end{array}$ & $\begin{array}{c}\text { Civil } \\
\text { Engineer } \\
\text { ing } \\
(8)\end{array}$ & $\begin{array}{c}\text { Analyti } \\
\text { cal } \\
\text { Chemis } \\
\text { try (32) }\end{array}$ \\
\hline $\begin{array}{l}\text { correct } \\
\text { answers }\end{array}$ & 11 & $8(65 \%)$ & $13(76 \%)$ & $4(75 \%)$ & $\begin{array}{c}15 \\
(38 \%)\end{array}$ \\
\hline $\begin{array}{l}\text { correct } \\
\text { answers per } \\
\text { stream }\end{array}$ & \multicolumn{3}{|c|}{$19(47.5 \%)$} \\
\hline sample & \multicolumn{3}{|c|}{$51(54.3 \%)$} \\
\hline
\end{tabular}

A summary of the scores for Cohort on B3 (Operations combined with SI units) is given in Table 16.

Table 16. Contingency Table - Cohort and B3 Score

\begin{tabular}{|c|c|c|c|c|c|c|c|c|}
\hline \multirow{3}{*}{$\begin{array}{c}\text { B3 } \\
\text { Score } \\
0 \text { to } \\
39\end{array}$} & \multicolumn{6}{|c|}{ Cohort } & \multirow{2}{*}{\multicolumn{2}{|c|}{ Total }} \\
\hline & \multicolumn{2}{|c|}{$\begin{array}{l}\text { Analytical } \\
\text { Chemistry }\end{array}$} & \multicolumn{2}{|c|}{ Civil Engineering } & \multicolumn{2}{|c|}{$\begin{array}{l}\text { Electrical } \\
\text { Engineering }\end{array}$} & & \\
\hline & 18 & $37 \%$ & 9 & $36 \%$ & 6 & $30 \%$ & 33 & $35 \%$ \\
\hline $\begin{array}{l}40 \text { to } \\
80\end{array}$ & 17 & $35 \%$ & 8 & $32 \%$ & 7 & $35 \%$ & 32 & $34 \%$ \\
\hline $\begin{array}{c}81 \text { to } \\
100\end{array}$ & 14 & $29 \%$ & 8 & $32 \%$ & 7 & $35 \%$ & 29 & $31 \%$ \\
\hline Total & 49 & $100 \%$ & 25 & $100 \%$ & 20 & $100 \%$ & 94 & 100 \\
\hline
\end{tabular}




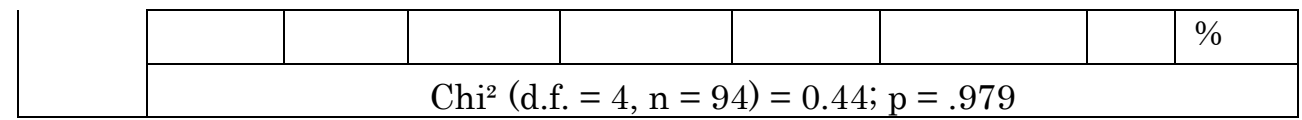

\section{RATIO AND PROPORTION (B4, 39.6\% AVERAGE) (Q 6, 7, 10 \& 12)}

An amount for rent $(\mathrm{R} 1,000)$ had to be proportionally shared amongst three people according to the number of cows each kept in a shared field (Q6). Only $30 \%$ of the students could do this correctly. Most incorrect answers were reached by dividing the amount by the number of people (three), instead of calculating the proportion according to the total number of cows each kept in the field. Although the total amount to be paid jointly by the three men was specified as R1,000, many answers exceeded this amount, and incorrect answers like R15,000.00, R3,300.33, R30,000.00, R130,000.00 and R36,000.00 were common. R30,000.00 was a popular answer, and it was reached by interpreting the joint amount payable, as an individual amount payable, depending on the number of cows each person kept in the field. Michael, who had 30 cows, would therefore have to pay R1,000.00 multiplied by 30 , which is R30,000.00. It seems that students taking part in this study, often executed operations perfunctorily without performing reality checks, which is common internationally (Blais \& Bath, 1992). Graffeo et al., (2015, p. 6) ascribe this phenomenon to low cognitive reflection levels, or "cognitive impulsivity", as measured by a cognitive reflection test (CRT). The researchers assert that this effect is partially counteracted by high numeracy levels.

In a subsequent question (Q7), students had to convert petrol consumption per $165 \mathrm{~km}$, to consumption per $100 \mathrm{~km}$, which involves ratio and proportion (DoBE, 2011a, p. 14). Correct answers were supplied by more than half (56.4\%) of the students (Table 17). Six students did not attempt the question at all. Since questions seven and twelve were similar, and could be solved with similar procedures, it is unclear why there is such a significant difference between the proportions of correct answers for the two questions. Only $24.5 \%$ of the students could answer Question 12 correctly (Table 19), whereas 56.4\% of the students answered Question seven correctly.

Table 17. Scores for Question 7

\begin{tabular}{|l|c|c|c|c|c|}
\hline \multicolumn{1}{|c|}{ Question 7 } & \multicolumn{2}{|c|}{ Mainstream } & \multicolumn{2}{c|}{ Extended Stream } \\
\hline & $\begin{array}{c}\text { Electrical } \\
\text { Engineering } \\
(20)\end{array}$ & $\begin{array}{c}\text { Civil } \\
\text { Engineering } \\
(17)\end{array}$ & $\begin{array}{c}\text { Analyti } \\
\text { cal } \\
\text { Chemi } \\
\text { stry } \\
(17)\end{array}$ & $\begin{array}{c}\text { Civil } \\
\text { Engineering } \\
(8)\end{array}$ & $\begin{array}{c}\text { Analyt } \\
\text { ical } \\
\text { Chemi } \\
\text { stry } \\
(32)\end{array}$ \\
\hline $\begin{array}{l}\text { correct } \\
\text { answers }\end{array}$ & $8(40 \%)$ & $11(65 \%)$ & $\begin{array}{c}13 \\
(76 \%)\end{array}$ & $6(75 \%)$ & 15 \\
\hline $\begin{array}{l}\text { correct } \\
\text { answers per } \\
\text { stream }\end{array}$ & \multicolumn{3}{|c|}{$32(59.3 \%)$} \\
\hline sample & \multicolumn{4}{|c|}{$53(56.4 \%)$} \\
\hline
\end{tabular}

In Question 10, students were required to convert a rate into an equivalent rate (DoBE, 2011a, p. 77). 
If I can walk $1 \frac{1}{5}$ kilometres in twelve minutes, how long will it take me at that rate to walk five kilometres? Answer in minutes.

The results are summarised in Table 18. Fewer than half of the students (46.8\%) answered correctly. Some students attempted to convert the rate to a rate per hour, by multiplying by 5 . Few of these students however proceeded to answer the question correctly. Another common mistake, especially amongst the extended stream students, was to translate a mixed fraction incorrectly to a decimal fraction, that is, $1 \frac{1}{5}$ was incorrectly converted to 1.5 . Most of the students, who presented incorrect answers for this question, showed no steps, and it was therefore difficult to analyse thought processes without interviewing the students.

Table 18. Scores for Question 10

\begin{tabular}{|c|c|c|c|c|c|}
\hline $\begin{array}{l}\text { Question } \\
10\end{array}$ & \multicolumn{2}{|c|}{ Mainstream } & \multicolumn{2}{c|}{ Extended Stream } \\
\hline & $\begin{array}{c}\text { Electrical } \\
\text { Engineering } \\
(20)\end{array}$ & $\begin{array}{c}\text { Civil } \\
\text { Engineering } \\
(17)\end{array}$ & $\begin{array}{c}\text { Analytical } \\
\text { Chemistry } \\
(17)\end{array}$ & $\begin{array}{c}\text { Civil } \\
\text { Engineering } \\
(8)\end{array}$ & $\begin{array}{c}\text { Analytical } \\
\text { Chemistry } \\
(32)\end{array}$ \\
\hline $\begin{array}{c}\text { correct } \\
\text { answers }\end{array}$ & $7(35 \%)$ & $13(76.5 \%)$ & $8(47.1 \%)$ & $3(38.5 \%)$ & $13(40.6 \%)$ \\
\hline $\begin{array}{c}\text { correct } \\
\text { answers } \\
\text { per } \\
\text { stream }\end{array}$ & $28(51.9 \%)$ & $16(40 \%)$ \\
\hline sample & \multicolumn{5}{|c|}{$44(46.8 \%)$} \\
\hline
\end{tabular}

Question 12 tested ratio and direct proportion (DoBE 2011a, p. 14). A girl's height was provided together with the length of the girl's shadow. Also, the length of a nearby pole's shadow was provided, and students had to calculate the height of the pole.

Very few of the students could present a correct answer (Table 19). Most students who presented incorrect answers, attempted to solve this problem by means of subtraction, i.e. they calculated the difference between the length of the girl's shadow and the girl's height, and then subtracted that amount from the length of the pole's shadow to obtain the pole's height, a process that yielded the incorrect answer of $6.5 \mathrm{~m}$, offered by $17(18.1 \%)$ of the students.

Table 19. Scores for Question 12

\begin{tabular}{|c|c|c|c|c|c|}
\hline $\begin{array}{l}\text { Question } \\
12\end{array}$ & \multicolumn{3}{|c|}{ Mainstream } & \multicolumn{2}{|c|}{ Extended Stream } \\
\hline & $\begin{array}{c}\text { Electrical } \\
\text { Engineerin } \\
\mathrm{g}(20)\end{array}$ & $\begin{array}{c}\text { Civil } \\
\text { Engineering } \\
(17)\end{array}$ & $\begin{array}{c}\text { Analytical } \\
\text { Chemistry } \\
(17)\end{array}$ & $\begin{array}{c}\text { Civil } \\
\text { Engineering } \\
(8)\end{array}$ & $\begin{array}{c}\text { Analytical } \\
\text { Chemistry } \\
(32)\end{array}$ \\
\hline $\begin{array}{c}\text { correct } \\
\text { answers }\end{array}$ & $2(10 \%)$ & $11(64.7 \%)$ & $3(17.6 \%)$ & $3(37.5 \%)$ & $4(12.5 \%)$ \\
\hline correct & \multicolumn{3}{|c|}{$16(29.6 \%)$} & \multicolumn{2}{c|}{$7(17.5 \%)$} \\
\hline
\end{tabular}




\begin{tabular}{|c|c|c|}
\hline $\begin{array}{c}\text { answers } \\
\text { per stream }\end{array}$ & & \\
\hline sample & $23(24.5 \%)$ & \\
\hline
\end{tabular}

A summary of the scores for Cohort for B4 (Ratio and proportion) is given in Table 20.

Table 20. Contingency Table - Cohort and B4 Score

\begin{tabular}{|c|c|c|c|c|c|c|c|c|}
\hline \multirow{3}{*}{$\begin{array}{c}\text { Mathematics } \\
\text { Grade } 12 \\
0-19 \% \\
\end{array}$} & \multicolumn{6}{|c|}{ Cohort } & \multicolumn{2}{|c|}{ Total } \\
\hline & \multicolumn{2}{|c|}{$\begin{array}{l}\text { Analytical } \\
\text { Chemistry }\end{array}$} & \multicolumn{2}{|c|}{$\begin{array}{c}\text { Civil } \\
\text { Engineering }\end{array}$} & \multicolumn{2}{|c|}{$\begin{array}{c}\text { Electrical } \\
\text { Engineering }\end{array}$} & \multirow[b]{2}{*}{21} & \multirow[b]{2}{*}{$22.3 \%$} \\
\hline & 12 & $24.5 \%$ & 2 & $8.0 \%$ & 7 & $35.0 \%$ & & \\
\hline $20-39 \%$ & 14 & $28.6 \%$ & 5 & $20.0 \%$ & 5 & $25.0 \%$ & 24 & $25.5 \%$ \\
\hline $40-60 \%$ & 14 & $28.6 \%$ & 8 & $32.0 \%$ & 5 & $25.0 \%$ & 27 & $28.7 \%$ \\
\hline $61-100$ & 9 & $18.4 \%$ & 10 & $40.0 \%$ & 3 & $15.0 \%$ & 22 & $23.4 \%$ \\
\hline Total & 49 & $100 \%$ & 25 & $100 \%$ & 20 & $100 \%$ & 94 & $100 \%$ \\
\hline & & $\mathrm{hi}^{2}$ & b, & 94) $=$ & $s, p$ & .198 & & \\
\hline
\end{tabular}

\section{PERCENTAGE AND PERCENTAGE INCREASE AND DECREASE (B5, 32.2\% AVERAGE) (Q 11, 13 \& 14)}

In the first question of this section (Q11), the total number of workers in a factory was given as the variable $P$, and the number of absentees was given as $N$. Students were expected to choose a formula, representing the percentage of absentees, from a list. This skill is prescribed in the Grade 7 syllabus as solving "problems in context involving percentages", but may very well be of a higher degree of difficulty because of the variables involved (DoBE, 2011a, p. 18). The majority of the incorrect answers (18 of 31 incorrect answers) were choice a, which reflected the percentage of workers absent, not those present. There was a noticeable difference between the mainstream (59.3\% of the answers correct) and the extended stream (52.5\% correct) (Table 21$)$.

Table 21. Scores for Question 11

\begin{tabular}{|l|c|c|c|c|c|}
\hline $\begin{array}{l}\text { Question } \\
11\end{array}$ & \multicolumn{2}{|c|}{ Mainstream } & \multicolumn{2}{|c|}{ Extended Stream } \\
\hline & $\begin{array}{c}\text { Electrical } \\
\text { Engineering } \\
(20)\end{array}$ & $\begin{array}{c}\text { Civil } \\
\text { Engineering } \\
(17)\end{array}$ & $\begin{array}{c}\text { Analytical } \\
\text { Chemistry } \\
(17)\end{array}$ & $\begin{array}{c}\text { Civil } \\
\text { Engineerin } \\
\mathrm{g}(8)\end{array}$ & $\begin{array}{c}\text { Analyti } \\
\text { cal } \\
\text { Chemis } \\
\text { try (32) }\end{array}$ \\
\hline $\begin{array}{l}\text { correct } \\
\text { answers }\end{array}$ & $11(55 \%)$ & $12(70.6 \%)$ & $9(52.9 \%)$ & $3(37.5 \%)$ & $\begin{array}{c}18 \\
(45 \%)\end{array}$ \\
\hline $\begin{array}{l}\text { correct } \\
\text { answers } \\
\text { per stream }\end{array}$ & \multicolumn{3}{|c|}{$32(59.3 \%)$} \\
\hline sample & \multicolumn{3}{|c|}{$53(56.4 \%)$} \\
\hline
\end{tabular}

In the second question of this section (Q13), students had to calculate the percentage increase in a price. Solving problems in contexts involving percentages, is a skill prescribed by the Grade 7 syllabus (DoBE, 2011a, p. 18). It is perturbing that so few students could answer this question correctly (Table 22), since lack of basic financial skills will most certainly hamper their 
"meaningful participation in society as citizens of a free country" (DoBE, 2011c, p. 18). These students will have to enter the free market and will encounter price increases on a daily basis as part of their work and personal environment. One of the common mistakes made was to calculate the difference between the original price and the raised price, (R15) and to assume this amount to be a percentage (incorrect answer 15\%). In some instances, students divided the difference (R15) by the new price (R70) when calculating a percentage, instead of dividing by the original price. Another common incorrect answer was $80 \%$. These students presumably divided the original price by the raised price (R60/R75) and then multiplied by 100 to convert to a percentage.

Table 22. Scores for Question 13

\begin{tabular}{|l|l|l|l|l|l|}
\hline Question 13 & & Mainstream & \multicolumn{2}{|l|}{ Extended Stream } \\
\hline & $\begin{array}{l}\text { Electrical } \\
\text { Engineeri } \\
\text { ng (20) }\end{array}$ & $\begin{array}{l}\text { Civil } \\
\text { Engineerin } \\
\mathrm{g}(17)\end{array}$ & $\begin{array}{l}\text { Analytical } \\
\text { Chemistry } \\
(17)\end{array}$ & $\begin{array}{l}\text { Civil } \\
\text { Engineerin } \\
\mathrm{g}(8)\end{array}$ & $\begin{array}{l}\text { Analy } \\
\text { tical } \\
\text { Chem } \\
\text { istry } \\
(32)\end{array}$ \\
\hline correct answers & $9(45 \%)$ & $7(41 \%)$ & $7(41 \%)$ & $5(63 \%)$ & $\begin{array}{l}6 \\
(15 \%)\end{array}$ \\
\hline $\begin{array}{l}\text { correct answers } \\
\text { per stream }\end{array}$ & \multicolumn{5}{|c|}{$34(36.2 \%)$} \\
\hline sample & $23(43 \%)$ \\
\hline
\end{tabular}

The final question (Q14) was:

The price of fuel has dropped by to R10.89. What was the price of fuel before the price decrease?

This question yielded by far the worst results (4.3\% correct answers, Table 23), which is disturbing, since the topic of financial mathematics features in the Grade 8 syllabus as Finance and Growth, emphasising how 'to solve problems, including annual interest, hire purchase, inflation, population growth and other real-life problems' (DoBE, 2011a, p. 18). Furthermore, the topic is repeated in the Grade 10 Mathematics syllabus, which prescribes that learners should understand the implication of 'fluctuating foreign exchange rates, for example on petrol price, imports, exports, overseas travel' (DoBE, 2011b, p. 26). The topic is examined in the first of two compulsory mathematics examination papers in Grade 8 and the question should be worth $10 \pm 3$ of the 100 marks for Grade 10, and $15 \pm 3$ marks for Grade 11 and 12 .

Table 23. Scores for Question 14

\begin{tabular}{|l|c|l|l|l|l|}
\hline $\begin{array}{l}\text { Question } \\
14\end{array}$ & \multicolumn{3}{|l|}{ Mainstream } & \multicolumn{2}{l|}{ Extended Stream } \\
\hline & $\begin{array}{l}\text { Electrical } \\
\text { Engineering }\end{array}$ & $\begin{array}{l}\text { Civil } \\
\text { Engineering }\end{array}$ & $\begin{array}{l}\text { Analytical } \\
\text { Chemistry }\end{array}$ & $\begin{array}{l}\text { Civil } \\
\text { Engineering }\end{array}$ & $\begin{array}{l}\text { Analytical } \\
\text { Chemistry }\end{array}$ \\
\hline $\begin{array}{l}\text { correct } \\
\text { answers }\end{array}$ & $1(5 \%)$ & $1(6 \%)$ & $1(6 \%)$ & 0 & $1(3 \%)$ \\
\hline correct & & & & \multicolumn{2}{c|}{$1(2.5 \%)$} \\
\hline
\end{tabular}




\begin{tabular}{|l|l|l|}
\hline $\begin{array}{l}\text { answers } \\
\text { per } \\
\text { stream }\end{array}$ & & \\
\hline sample & $4(4.3 \%)$ \\
\hline
\end{tabular}

A summary of the scores for Cohort for B5 (Percentage and percentage increase and decrease) is given in Table 24 .

Table 24. Contingency Table - Cohort and B5 Score

\begin{tabular}{|c|c|c|c|c|c|c|c|c|}
\hline \multirow{3}{*}{$\begin{array}{l}\text { B5 Score } \\
0 \text { to } 19\end{array}$} & \multicolumn{6}{|c|}{ Cohort } & \multirow{2}{*}{\multicolumn{2}{|c|}{ Total }} \\
\hline & \multicolumn{2}{|c|}{$\begin{array}{l}\text { Analytical } \\
\text { Chemistry }\end{array}$} & \multicolumn{2}{|c|}{$\begin{array}{c}\text { Civil } \\
\text { Engineering }\end{array}$} & \multicolumn{2}{|c|}{$\begin{array}{c}\text { Electrical } \\
\text { Engineering }\end{array}$} & & \\
\hline & 15 & $30.6 \%$ & 6 & $24.0 \%$ & 4 & $20.0 \%$ & 25 & $26.6 \%$ \\
\hline 20 to 39 & 27 & $55.1 \%$ & 11 & $44.0 \%$ & 11 & $55.0 \%$ & 49 & $52.1 \%$ \\
\hline 60 to 100 & 7 & $14.3 \%$ & 8 & $32.0 \%$ & 5 & $25.0 \%$ & 20 & $21.3 \%$ \\
\hline Total & 49 & $100 \%$ & 25 & $100 \%$ & 20 & $100 \%$ & 94 & $100 \%$ \\
\hline
\end{tabular}

The data in this study indicated that most first-year entry level science and engineering diploma students at this particular university in South Africa still struggle with fractions. The average score of $47.8 \%$ was disappointing. So was the highest score-only $86 \%$. Several colleagues opined that they expected students to score at least $90 \%$ for this particular test. In a study done at the University of Johannesburg, $90 \%$ was expected as a pass rate for a test based on Grade 6 work (Fonseca \& Petersen 2015). For a diagnostic test to assess the mathematical knowledge of students enrolling in its B.Ed. program, the University of New England expected a mastery level of $80 \%$. The Khan online academy encourages $100 \%$ mastery for basic numeracy (Fonseca \& Petersen 2015). In nursing education, $90 \%$ is usually regarded as a competent score for numerical drug calculations in research, although no justification for this figure is given and Jukes and Gilchrist (2006) are of the opinion that $100 \%$ mastery should be achieved in tests on the administration of medicines. The authors of the present research anticipated a mastery score of above $90 \%$ for numeracy tests for engineering and science students at entry level.

These results compare poorly to the results of an international study by Siegler et al. (2011) in which mathematics and science students answered consistently correct on questions on multiplications and division of fractions. However, results from the present study are better than those Akyuz (2015) reported from a study conducted by a university in Turkey on students who were in a two-year program at a technical vocational school. They were tested on numeracy and basic algebraic skills and their average score was only 6.32 out of a total of twenty points (31.6\%).

There was a marked difference in the performance of the mainstream and the extended stream students (Table 3). Numeracy seems to be a stumbling block for those in the extended stream. Students should be assisted to overcome these problems. "Giving access to students from disadvantaged backgrounds without providing the environment in which they can succeed academically is commonly termed the revolving door syndrome" (Case, 2006, p. 25). Academic 
support programs should include quantitative skills. A study by Campbell (2009) in mathematics, and another by Kremmer et al. (2010) in the field of business, showed that remedial programmes at tertiary education institutions had a positive impact on students' success at university.

Data collected pointed to lack of conceptual understanding of operations on fractions. This is a common problem internationally (Siegler \& LortieForgues, 2015). Especially in the case where no calculators are allowed, procedural mastery does not necessarily imply conceptual understanding. Students may remember the procedure without ever having understood the theoretical underpinning for the procedure. This may also apply to teachers ( $\mathrm{Ma}$, 1999). Consistent with this interpretation, $\mathrm{Ma}$ (1999) found that most United States teachers in her study could not generate any explanation of what $1 \frac{3}{4} \div \frac{1}{2}$ means, or resorted to explaining a different problem, i.e. $1 \frac{3}{4} \div 2$. A study by Ball (1990) revealed similar results. Teachers in other local and international studies have demonstrated weak conceptual understanding of fraction arithmetic (Lin et al., 2013; Ma, 1999; Rizvi \& Lawson, 2007). A study conducted at five South African universities reported that prospective teachers enter university programmes with reasonable procedural knowledge of mathematics but poor conceptual knowledge (Bowie, 2014).

Similar problems occur when students have to multiply by fractions with magnitude smaller than one. Teachers should emphasize that multiplication and division produce different outcomes depending on whether the numbers involved are greater or lesser than 1 , and should discuss why this is true. 'Chinese textbooks include such instruction' (Siegler \& Lortie-Forgues, 2015). To strengthen their case, these researchers referred to an example given by Sun and Wang (2005) in which Chinese students were asked to solve and discuss answers to the following three problems: $4.9 * 1.01 ; \quad 4.9 * 1 ; \quad 4.9 * 0.99$.

Jukes and Gilchrist (2006) observe that a lack of retention may be to blame. Some of the students involved in this research may have understood the concepts at the time when these were explained to them, but may have forgotten at the time of this study. Johnson and Johnson (2002) claim that the educational institution and the student should share the responsibility for both attainment and retention of skills.

Reports of studies done by various researchers (Siegler et al., 2011; Booth \& Newton, 2012; Torbeyns et al., 2014; Wu, 2001) emphasise the importance of magnitude representations of fractions on number lines when teaching fractions, as opposed to the part-of-a-whole approach. Some countries focus almost exclusively on the part-whole approach and neglect the number-line approach. South African teaching seems to fall into the latter category. Both methods should be incorporated into the pedagogy of teaching fractions in order to supplement and complement each other.

\section{Conclusions and Suggestions}

The current study revealed that entry-level students enrolled for engineering and science diplomas performed poorly in a test of numeracy skills. 
The average score (47.8\%) was regarded as a cause for concern, especially considering that the test was pitched at Grade 8 level. The average score was far below the researchers' expectations. Furthermore, students displayed a lack of conceptual understanding of the procedures. This study also revealed a marked difference between the performance of the mainstream and the extended stream students.

Mathematics lecturers at universities and mathematics teachers at secondary schools should take note of the results of this study. First year university lecturers at universities need to offer remedial action, especially for students in the extended stream. Furthermore, problems with conceptual understanding of fractions could possibly be ascribed to conceptual problems that teachers might have had with fractions. Hence, one approach to addressing students' difficulties with fractions would be to conduct in-service workshops to refresh practicing teachers' subject content knowledge and pedagogical content knowledge in order to enhance teachers' conceptual knowledge of fractions so as to promote effective teaching and learning activities.

Even people who are proficient in fraction procedures often possess weak conceptual understanding of multiplication and division of fractions less than 1. Literature highlights that specific teaching approaches may yield improved results, especially in this instance. Teachers should point out to students that multiplication and division produce different outcomes depending on whether the numbers involved are greater than or less than 1, and should discuss why this is so.

Lastly, the importance of magnitude representations of fractions on number lines, as opposed to the part-of-a-whole approach to teaching fractions, does need emphasis. Both methods should be incorporated into the pedagogy when teaching fractions.

Further research should examine whether a cause-effect relationship exists between reflective reasoning and mathematics scores in general, and if so, whether it is possible to improve students' cognitive reflection in mathematics. Also, various studies have found fraction knowledge to be an early and accurate predictor of later mathematics achievement. These predictions may extend to predictions of tertiary mathematics success. Possible links between fraction test scores and tertiary students' pass rates in mathematics should be explored. It may well transpire that scores on fraction tests could be used as a predictive measure for the eventual academic success in mathematics service courses at university. If a positive correlation does exist, further research should be conducted on whether remedial measures on fraction skills will positively influence students' ensuing academic achievement in higher education. Mathematics educators have asserted that this may indeed be the case, but more research is required to confirm that the conceptual mastery of lower-level fraction skills will positively impact students' achievement in mathematics service courses at tertiary level. Pre-service mathematics educators also need to note the results of this study so as to equip student teachers with both subject content knowledge and pedagogical content knowledge of fractions.

The current study did not make use of interviews, and interpretation of student errors were therefore limited. Interviews would elicit the processes students used to reach answers, and the reasoning underpinning these. The 
researcher would then be able to reach more detailed conclusions regarding the levels of conceptual understanding that cause university entry level students' incorrect answers.

The sample in this study was relatively small, but there is no reason to assume that the findings cannot be generalised to other diploma students in science and engineering, provided that the admission requirements for the diplomas are compatible.

The current study revealed that entry-level students enrolled for engineering and science diplomas performed poorly in a test of numeracy skills. The average score $(47.8 \%)$ was regarded as a cause for concern, especially considering that the test was pitched at Grade 8 level. The average score was far below the researchers' expectations. Furthermore, students displayed a lack of conceptual understanding of the procedures. This study also revealed a marked difference between the performance of the mainstream and the extended stream students.

Mathematics lecturers at universities and mathematics teachers at secondary schools should take note of the results of this study. First year university lecturers at universities need to offer remedial action, especially for students in the extended stream. Furthermore, problems with conceptual understanding of fractions could possibly be ascribed to conceptual problems that teachers might have had with fractions. Hence, one approach to addressing students' difficulties with fractions would be to conduct in-service workshops to refresh practicing teachers' subject content knowledge and pedagogical content knowledge in order to enhance teachers' conceptual knowledge of fractions so as to promote effective teaching and learning activities.

Even people who are proficient in fraction procedures often possess weak conceptual understanding of multiplication and division of fractions less than 1 . Literature highlights that specific teaching approaches may yield improved results, especially in this instance. Teachers should point out to students that multiplication and division produce different outcomes depending on whether the numbers involved are greater than or less than 1, and should discuss why this is so.

Lastly, the importance of magnitude representations of fractions on number lines, as opposed to the part-of-a-whole approach to teaching fractions, does need emphasis. Both methods should be incorporated into the pedagogy when teaching fractions.

Further research should examine whether a cause-effect relationship exists between reflective reasoning and mathematics scores in general, and if so, whether it is possible to improve students' cognitive reflection in mathematics. Also, various studies have found fraction knowledge to be an early and accurate predictor of later mathematics achievement. These predictions may extend to predictions of tertiary mathematics success. Possible links between fraction test scores and tertiary students' pass rates in mathematics should be explored. It may well transpire that scores on fraction tests could be used as a predictive measure for the eventual academic success in mathematics service courses at university. If a positive correlation does exist, further research should be conducted on whether remedial measures on fraction skills will positively 
influence students' ensuing academic achievement in higher education. Mathematics educators have asserted that this may indeed be the case, but more research is required to confirm that the conceptual mastery of lower-level fraction skills will positively impact students' achievement in mathematics service courses at tertiary level. Pre-service mathematics educators also need to note the results of this study so as to equip student teachers with both subject content knowledge and pedagogical content knowledge of fractions.

The current study did not make use of interviews, and interpretation of student errors were therefore limited. Interviews would elicit the processes students used to reach answers, and the reasoning underpinning these. The researcher would then be able to reach more detailed conclusions regarding the levels of conceptual understanding that cause university entry level students' incorrect answers.

The sample in this study was relatively small, but there is no reason to assume that the findings cannot be generalised to other diploma students in science and engineering, provided that the admission requirements for the diplomas are compatible.

\section{Disclosure statement}

No potential conflict of interest was reported by the authors.

\section{Notes on contributors}

Coetzee - Department of Applied Information and Mathematics, Walter Sisulu University, East London, South Africa

Mammen - School of General and Continuing Education, University of Fort Hare, East London, South Africa

\section{References}

Akyuz, G. (2015). Determining the Numeracy and Algebra Errors of Students in a Two-year Vocational School. Community Collge Journal of Research and Practice, 39(3), 252-264.

Bailey, D.H, Zhou. X., Zhang, Y., Cui, J., Fuchs, L.S., Jordan, N. C., Gersten, R. \& Siegler, R. S. (2015). Development of fraction concepts and procedures in U.S and Chinese children. $J$ Exp Child Psychol, 129, 6883.

Ball, D.L. (1990). The mathematical understandings that prospective teachers bring to teacher education. THe Elementary School Journal, 90, 449466.

Barwell, R. (2004). What is Numeracy? For the Learning of Mathematics, 24(1), 20-22.

Blais, K. \& Bath, J. (1992). Drug calculation errors of baccalaureate nursing students. Nurse Educator, 17(1), 12-15. 
Bone, A. A., Carr, J. A, Daniele, V.A., Fisher, R., Fones, N .B., Innes, J. I., Maher, H. P., Osborn, H.G. \& Rockwell, D.L. (1984). Promoting a clear path to technical education. Washington DC: Model Secondary School for the Deaf.

Booth, J.L. \& Newton, K.J. (2012). Fractions: Could they really be the gatekeeper's doorman? Contemporary Educational Psychology, 374), 247-253.

Booth, J.L., Newton, K.J. \& Twiss-Garrity, L.K. (2014). The impact of fraction magnitude knowledge on algebra performance and learning. Journal of Experimental Child Psychology, 118, 110-118.

Bowie, L. (2014). Report on mathematics courses for intermediate phase student teachers at five universities. Johannesburg: JET Education Services. Retrieved $24 \quad$ March $2016 \quad$ from http://www.jet.org.za/publications/initial-teacher-education-researchproject/copy_of_bowie-report-on-maths-courses-offered-at-5-case-studyinstitutions-18-feb.pdf.

Bowie, L. \& Frith, V. (2006). Concerns about the South African Mathematical Literacy curriculum arising from experience of material development. Pythagoras, 64, 29-36.

Brousseau, G., Brousseau, N. \& Warfield, V. (2004). Rationals and decimals as required in the school curriculum. Part 1: Rationals as measurements. Journal of Mathematical Behavior, 23, 1-20.

Cai, J. (1995). A Cognitive Analysis of U. S. and Chinese Students' Mathematical Performance on Tasks Involving Computation, Simple Problem Solving, and Complex Problem Solving (Vol. monograph series 7). Reston, VA: National Council of Teachers of Mathematics.

Campbell, A. (2009). Remediation of First-year mathematics students algebra difficulties. (MSc), University of KwaZulu-Natal, KwaZulu-Natal, South Africa. Retrieved 30 April 2014 from http://researchspace.ukzn.ac.za/xmlui/bitstream/handle/10413/761/Cam pbell_A_2009.pdf? sequence $=1$

Case, J. (2006). Issues facing engineering education in South Africa. Paper presented at the Engineering Education for Sustainable Development: Proceedings of the 3rd African Regional Conference, 26-27 September 2006, University of Pretoria, Pretoria, South Africa, 26-27 September 2006.

Cetin, H \& Ertekin, E. (2011). The relationship between eighth grade primary school students' proportional reasoning skills and success in solving equations. International Journal of Instruction, 4(1), 47-62. 
Clarke, D. (2006). Fractions as division: The forgotten notion. Australian Primary Mathematics Classroom, 11(3), 4-10.

Coetzee, J. \& Mammen, K. J. (2016). Challenges Faced by Entry-level University Students in Word Problems Involving Fractions Terminology. International Journal of Education Sciences (IJES)., 15(3), 461-473.

DoBE, (2011a). National Curriculum Statement (NCS): Curriculum and Assessment Policy Statement (CAPS) Further Education and Training Phase MATHEMATICS GR 7-9. Pretoria: Department of Basic Education. Retrieved 30 April 2014 from http://www.education.gov.za.

DoBE, (2011b). National Curriculum Statement (NCS): Curriculum and Assessment Policy Statement (CAPS) Further Education and Training Phase MATHEMATICS Grades 10-12. Pretoria, South Africa: Department of Basic Education. Retrieved 30 April 2014 from http://www.education.gov.za.

DoBE, (2011c). National Curriculum Statement (NCS): Curriculum and Assessment Policy Statement (CAPS) Intermediate Phase MATHEMATICS GR 4-6. Pretoria: Department of Basic Education. Retrieved 30 April 2014 from http://www.education.gov.za.

DoBE, (2012). National Senior Certificate 2012: National diagnostic report on learners' performance. Pretoria, South Africa: Department of Basic Education. Retrieved 15 October 2015 from http://www.education.gov.za.

Dorko, A \& Speer, N. (2014). Calculus Students' Understanding of Units. Paper presented at the 17th Annual Conference on Research in Undergraduate Mathematics Education, February 26 - March 2, 2014, Denver, Colorado.

Duffin, J. (2003). Numeracy in Higher Education. In J. K. Peter Kahn (Ed.), Effective Learning and Teaching in Mathematics and Its Applications: Routledge, London.

Fonseca, K \& Petersen, N. (2015). Online supplementary mathematics tuition in a first-year childhood teacher education programme. South African Journal of Childhood Education, 5(3), 9 pages.

Gabaldon, T.A. (2015). Strength in Numbers: Teaching Numeracy in the Context of Business Associations. St. Louis University Law Journal, 59, 701709 .

Graffeo, M., Polonio, L. \& Bonini, N. (2015). Individual differences in competent consumer choice: the role of cognitive reflection and numeracy skills. Frontiers in Psychology, 6. 
Gravetter, F.J. \& Wallnau, L.B. (2009). Statistics for the Behavioral Sciences (8th ed.). Belmont, CA: Wadsworth.

Houston, J., Tenza, S.P., Hough, S., Singh, R. \& Booyse, C. (2015). The rationale for teaching Quantitative Literacy in 21st century South Africa: A case for the renaming of Mathematical Literacy. The Independent Journal of Teaching and Learning, 10. Retrieved 6 April 2016 from http://hdl.handle.net/11622/53

Johnson, A.W. \& Johnson, R. (2002). Cooperative Learning Methods: A metaanalysis. Journal of Research in Education, 12(1), 5-14.

Jukes, L \& Gilchrist, M. (2006). Concerns about numeracy skills of nursing students. Education in Practice, 6(4), 192-198.

Kremmer, M., Brimble, M., Freudenberg, B. \& Cameron, C. (2010). Numeracy of First Year Commerce Students: Preliminary Analysis of an Intervention. The International Journal of Learning, 17(1), 1-13.

Lamon, S.L. (2001). Presenting and Representing: From Fractions to Rational Numbers. In A. Cuoco \& F. Curcio (Eds.), The Roles Of Representations in School Mathematics-2001 Yearbook (pp. 146-165). Reston: NCTM.

Lesh, R., Post, T. \& Behr, M. (1988). Proportional Reasoning. In J. Hiebert \& M. Behr (Eds.), Number Concepts and Operations in the Middle Grades (pp. 93-118). Reston, VA: Lawrence Erlbaum \& National Council of Teachers of Mathematics.

Lin, C.Y., Becker, J., Byun, M-R., Yang, D.C. \& Huang, T.W. (2013). Preservice Teachers' Conceptual and Procedural Knowledge of Fraction Operations: A Comparative Study of the United States and Taiwan. School Science and Mathematics, 113(1), 41-51.

Livy, S. \& Herbert, S. (2013). Second-Year Pre-Service Teachers' Responses to Proportional Reasoning Test Items. Australian Journal of Teacher Education, 38(11), 17-32.

Long, C., Dunne, T. \& De Kock, H. (2014). Mathematics, curriculum and assessment: The role of taxonomies in the quest for coherence. Pythagoras 35, 35(2), 14.

Lortie-Forgues, H., Tian, J. \& Siegler, R.S. (2015). Why Is Learning Fraction and Decimal Arithmetic So Difficult. Developmental Review, 38, 201221.

Ma, L. (1999). Knowing and teaching elementary mathematics: Teachers' knowledge of fundamental mathematics in China and the United States. Mahwah, NJ: Erlbaum. 
Naureen, D. \& Vicki, N.T. (2012). The role of numeracy skills in graduate employability. Education and Training, 54(5), 419-434.

NMAP, (2008). Foundations for Success: The final report of the National Mathematics Advisory Panel. Washington, DC: National Mathematics Advisory Panel. Retrieved 27 February 2016 from http://www2.ed.gov/about/bdscomm/list/mathpanel/report/finalreport.pdf.

OECD, (2013). OECD Skills Outlook 2013: First Results from the Survey of Adult Skills. Paris: OECD Publishing. Retrieved 4 April 2016 from www.oecd.org/skills/.

Pienaar, E. (2014). Learning About And Understanding Fractions And Their Role In The High School Curriculum. (Master of Education), University of Stellenbosch, Stellenbosch. Retrieved 15 October 2015 from https://www.google.co.za/\#q=Learning+About+And+Understanding+Fr actions+And+Their+Role+In+The+High+School+Curriculum

Pinker, S. (1998). How the mind works. London: Penguin Books

Reyna, V.F., Nelson, W.L., Han, P.K. \& Dieckmann, N.F. (2009). How Numeracy Influences Risk Comprehension and Medical Decision Making. Psychological bulletin, 135(6), 943-973.

Rivera-Batiz, F.L. (1992). Quantitative Literacy and the Likelihood of Employment among Young Adults in the United States. The Journal of Human Resources, 27(2), 313-328.

Rizvi, N.F. \& Lawson, M.J. (2007). Prospective teachers' knowledge: Concept of division International Education Journal, 8(2), 377-392.

Roohr, K.C., Graf, E.A. \& Liu, O.L. (2014). Assessing Quantitative Literacy in Higher Education: An Overview of Existing Research and Assessments With Recommendations for Next-Generation Assessment. ETS Research Report Series, 2014(2), 1-26.

Schneider, M. \& Siegler, R.S. (2010). Representations of the magnitudes of fractions. Journal of Experimental Psychology: Human Perception and Performance, 36(5), 1227-1238.

Schollar, E. (2008). Towards Evidence-based Educational Development in South Africa: Eric Schollar and Associates c.c. Retrieved 21 March 2016 from https://www.ru.ac.za/media/rhodesuniversity/content/sanc/documents/S chollar\%20-\%202008\%20\%20Final\%20Report\%20Short\%20Version\%20The\%20Primary\%20Mat hematics\%20Research\%20Project\%202004-2007\%20\%20Towards\%20eveidence-based\%20educational\%20de.pdf. 
Siegler, R.S., Duncan, G.J ., Davis-Kean, P.E., Duckworth, K., Claessens, A., Engel, M., Susperreguy, M.I. \& Chen, M. (2012a). Early Predictors of High School Mathematics Achievement. Psychological Science, 23(7), 691-697.

Siegler, R.S., Fazio, L.K., Bailey, D.H. \& Zhou, X. (2012b). Fractions: the new frontier for theories of numerical development. Trends in Cognitive Sciences, 17(1), 13-19.

Siegler, R.S. \& Lortie-Forgues H. (2015). Conceptual Knowledge of Fraction Arithmetic. Journal of Educational Psychology, 107(3), 909-918.

Siegler, R.S. \& Thompson, CA. (2014). Numerical landmarks are useful-except when they're not. J Exp Child Psychol, 120, 39-58.

Siegler, R.S., Thompson, C.A. \& Schneider, M. (2011). An integrated theory of whole number and fractions development. Cognitive Psychology, 62(2011), 273-296.

Spaull, N. \& Kotze, J. (2015). Starting behind and staying behind in South Africa: The case of insurmountable learning deficits in mathematics. International Journal of Educational Development, 41, 13-24.

Sun, L.G. \& Wang, L. (2005). Mathematics: Spring, Fifth grade. Nanjing, Jiangsu Province: Phoenix Education.

Titus, J. (1995). The concept of fractional number among deaf and hard of hearing students. American Annals of the Deaf, 140(3), 255-263.

Torbeyns, J., Schneider, M., Xin, Z, \& Siegler, R.S. (2014). Bridging the Gap: Fraction understanding is central to mathematics achievement in students from three different continents. Learning and Instruction, 1-9.

Torbeyns, J., Schneider, M., Xin, Z. \& Siegler R.S. (2015). Bridging the gap: Fraction understanding is central to mathematics achievement in students from three different continents. Learning and Instruction, 37, 5-13.

Watts, T.W., Duncan, G.J., Siegler, R.S. \& Davis-Kean, P.E. (2014). What's Past Is Prologue: Relations Between Early Mathematics Knowledge and High School Achievement. Educational Researcher, 43(7), 352-360.

Wilson, T.M. \& MacGillivray, H.L. (2007). Counting on the basics: mathematical skills among tertiary entrants. International Journal of Mathematical Education in Science and Technology, 38(1), 19-41.

Wu, H. (2001). How to prepare students for Algebra. American Educator, 25(2), 10-17. 